\title{
THE IMPACT OF STANDARDISATION METHOD ON SMART CITY RANKING
}

\author{
Adam SOJDA $^{1^{*}}$, Maciej WOLNY ${ }^{2}$ \\ ${ }^{1}$ Silesian University of Technology, Poland; adam.sojda@polsl.pl, ORCID: 0000-0002-3021-4451 \\ ${ }^{2}$ Silesian University of Technology, Poland; maciej.wolny@polsl.pl, ORCID: 0000-0002-8872-7794 \\ * Correspondence author
}

Purpose: The main purpose of the work is to present the impact of standardisation methods on the ranking results. The second purpose of the article was to present Warsaw's position in comparison with the capitals of countries from the Eurozone.

Design/methodology/approach: Major European cities were assessed using Eurostat data. The proprietary Smart City Index (SCI) indicator is proposed for the study, referring to six areas of Smart City assessment. Two measures are indicated in each of them. The first is an objective measure, while the second is a subjective measure, based on the opinion of the city's residents about the situation in the city, or their own situation.

Building rankings of the cities, following normalisation methods were used and compared: unitisation, unitisation with zero minimum, normalisation in range $[-1,1]$, classical standardisation, Weber standardisation and two quotient methods.

Findings: The best results were obtained for the classical standardisation. For this method we obtained the smallest number of consistent positions in rankings and the minimal maximum of distance between the positions in rankings. The position of Warsaw as a city in 16th position (20 of all) was confirmed regardless of the standardization method used.

Originality/value: There is proposed an original method to assess cities based on Eurostat data. This method allows construction of Smart City ranking. The main value of the work is that the classical standardisation is recommended to transform the original values of individual indicators.

Keywords: standardisation method, Smart City, Eurostat.

Category of the paper: Research paper.

\section{Introduction}

The Smart City concept is not a new concept, but it is continuously developed. Currently, the concepts referred to as Smart City 5.0 are presented (Svítek, 2020). Regardless of the version presented, Smart City is a concept for urban development. It is composed of a complex 
hierarchical structure. The areas of development, to which the concept of Smart City refers, are: economy, people, management, mobility, environment, quality of life (Giffinger et al., 2007). Due to the hierarchy, it is possible to break it down into areas, subareas, factors and indicators (Boech et al., 2017a). This presents an opportunity to measure and evaluate Smart City solutions.

Due to the complexity of the Smart City concept itself, there are no unequivocal assessment methods. There are many concepts for Smart City assessment. Table 1 presents selected assessment systems. Each of them is characterised by an individualised approach to the issue in the sphere of variables, as well as the analysed cities.

Table 1.

Selected Smart City assessment systems

\begin{tabular}{|c|c|}
\hline Name & Description \\
\hline $\begin{array}{l}\text { European } \\
\text { Smart Cities } \\
\text { Ranking }\end{array}$ & $\begin{array}{l}\text { European ranking compiled by an international consortium chaired by the University of } \\
\text { Technology in Vienna. It includes, among others: Bydgoszcz, Gdańsk, Katowice, Kraków, } \\
\text { Łódź, Lublin, Poznań, Szczecin and Wrocław. } \\
\text { It consists of } 6 \text { categories and } 64 \text { indicators. Giffinger et al. (2007) } \\
\text { http://www.smart-cities.eu/ } \\
\text { (accessed on: 09.10.2019) }\end{array}$ \\
\hline $\begin{array}{l}\text { The Smart } \\
\text { Cities Wheel }\end{array}$ & $\begin{array}{l}\text { A holistic assessment system, taking into account the key elements that make up a Smart City. } \\
\text { A tool to support city benchmarking. Compiled by Boyd Cohen, in collaboration with leading } \\
\text { cities around the world. } \\
\text { It includes } 6 \text { categories and } 62(28) \text { indicators. Boyd Cohen } \\
\text { https://www.fastcompany.com/1680538/what-exactly-is-a-smart-city } \\
\text { https://www.fastcompany.com/3038818/the-smartest-cities-in-the-world-2015-methodology } \\
\text { (accessed on: } 09.10 .2019)\end{array}$ \\
\hline $\begin{array}{l}\text { Bilbao Smart } \\
\text { Cities Study }\end{array}$ & $\begin{array}{l}\text { initiated at the world summit in Bilbao, giving an overview of the situation in cities } \\
\text { rent regions of the world. Includes, among others, Katowice. } \\
\text { ists of } 6 \text { categories and } 49 \text { indicators. UCLG }(2012) \\
\text { Jww.uclg-digitalcities.org/app/uploads/2015/06/en_smartcitiesstudy.pdf } \\
\text { ed on: } 09.10 .2019 \text { ) }\end{array}$ \\
\hline $\begin{array}{l}\text { Triple-helix } \\
\text { network } \\
\text { model } \\
\text { for smart cities } \\
\text { performance }\end{array}$ & $\begin{array}{l}\text { Model analysing the links between smart city components, including social relations. It uses } \\
\text { a modified triple helix model applied in innovation analysis. } \\
\text { It consists of } 5 \text { categories and } 45 \text { indicators. } \\
\text { Lombardi et al., (2011) http://degree.ubvu.vu.nl/repec/vua/wpaper/pdf/20110045.pdf } \\
\text { (accessed on: } 09.10 .2019)\end{array}$ \\
\hline $\begin{array}{l}\text { Smart City } \\
\text { PROFILES }\end{array}$ & $\begin{array}{l}\text { A set of } 21 \text { Smart City indicators, with particular emphasis on climate change and energy } \\
\text { efficiency. Indicators include } 5 \text { categories. Smart City PROFILES (2013) } \\
\text { https://www.smartcities.at/assets/03-Begleitmassnahmen/SmartCity-PDF-INTRO.pdf } \\
\text { (accessed on: } 09.10 .2019)\end{array}$ \\
\hline CITYkeys & $\begin{array}{l}\text { An EU project (under the H2020 program) aimed at providing a validated, holistic framework } \\
\text { for measuring and assessing Smart Cities. Also in the context of city and project } \\
\text { implementation. It consists of } 73 \text { indicators in } 5 \text { main categories. } \\
\text { Bosch et al. (2017a, 2017b), Huovila et al. (2016) http://www.citykeys-project.eu/ } \\
\text { (accessed on: } 09.10 .2019)\end{array}$ \\
\hline $\begin{array}{l}\text { CIMI (City In } \\
\text { Motion } \\
\text { Index), IESE } \\
\text { Cities in } \\
\text { Motion Index }\end{array}$ & $\begin{array}{l}\text { Project implemented by the Business School University of Navarra. } 10 \text { key assessment areas } \\
\text { and } 96 \text { indicators are considered. The concept is being developed. In } 2019,13 \text { more indicators } \\
\text { are considered than in the previous year. Of the } 174 \text { cities evaluated, there are } 2 \text { Polish cities: } \\
\text { Warsaw and Wroclaw. } \\
\text { https://media.iese.edu/research/pdfs/ST-0509-E.pdf (accessed on: } 10.11 .2019 \text { ) DOI: } \\
\text { https://dx.doi.org/10.15581/018.ST-509 }\end{array}$ \\
\hline
\end{tabular}

Source: Compiled on the basis of: Ahvenniemi et al. (2017), Giffinger et al. (2007), UCLG (2012), Lombardi et al. (2011), Smart City PROFILES (2013), Berone et al. (2019). 
Smart City assessment systems require the use of different databases. The methodology of building the assessment in published rankings is not usually precisely presented. Indicators describing the city belong to different categories. When constructing a ranking, one must choose how to standardise the data to enable comparison.

The main purpose of the work is to present the impact of standardisation methods on the ranking results. Due to the purpose of the work, without losing sight of the overall picture, it is possible to narrow the discussion down to the European capitals and make use of the possibility of automatic use of the Eurostat database (Sojda et al., 2018), as well as (SzczechPietkiewicz, 2015), in particular, the ranking methodology used, based on the Eurostat database.

\section{Smart City Index}

Eurostat (European Statistical Office) is the office of the European Commission, which deals with analyses and forecasts for Europe, based on statistical data of individual countries. One of the forms of activity is providing access to databases. The database also includes an area dedicated to cities and urban areas (Urban Audit). From the point of view of variables, it can be stated, that there are up to 183 indicators in the database describing a selected city, with 1783 cities.

The concept refers to a broadly understood notion of a "smart city". It means six basic aspects related to the functioning of a city: economy, human capital, management, mobility, environment, quality of life.

The proprietary Smart City Index (SCI) indicator was proposed for the study, referring to six areas of Smart City assessment. Two measures are indicated in each of them. The first is an objective measure, while the second is a subjective measure, based on the opinion of the city's residents about the situation in the city, or their own situation.

Table 2.

Smart City area measures

\begin{tabular}{|c|c|}
\hline Area & Measure \\
\hline economy & $\begin{array}{l}\text { EC1 - unemployment rate } \\
\text { EC2 - household financial situation, according to the opinions of residents }\end{array}$ \\
\hline human capital & $\begin{array}{l}\text { PE1 - median population age } \\
\text { PE2 - schools in the city, according to the opinions of residents }\end{array}$ \\
\hline management & $\begin{array}{l}\text { MA1 - employment in public administration to total employment rate } \\
\text { MA2 - trust in public administration of the city }\end{array}$ \\
\hline mobility & $\begin{array}{l}\text { MO1 - percentage of foreigners in the population, as a proportion of population } \\
\text { MO2 - assessment of public transport by residents }\end{array}$ \\
\hline environment & $\begin{array}{l}\text { EN1 - annual average concentration of PM10 }\left(\mu \mathrm{g} / \mathrm{m}^{3}\right) \\
\text { EN2 - noise level assessment by city residents }\end{array}$ \\
\hline quality of life & $\begin{array}{l}\text { QL1 - natural growth (Crude birth rate per } 1000 \text { residents) } \\
\text { QL2 - assessment of satisfaction from living in this city }\end{array}$ \\
\hline
\end{tabular}




$$
\mathrm{SCI}=\frac{\sum O I_{i} w_{i}}{\sum w_{i}}
$$

for the area

$$
O I_{i}=\frac{\sum I_{i j} v_{i j}}{\sum v_{i j}}
$$

where

$I_{i j}$ - value of the $\mathrm{j}$-th variable, a measure included in the $\mathrm{i}$-th area,

$v_{i j}$ - weight of the $\mathrm{j}$-th variable, the measure included in the $\mathrm{i}$-th area $\sum_{j} v_{i j}=1$,

$O I_{i}$ - index value for the $i$-th area,

$w_{i}$ - the weight of the $\mathrm{i}$-th area $\sum_{i} w_{i}=1$,

all weights are non-negative.

The indicator includes the following relationships between areas and their measures. It was considered that, for determining the SCI value, each area would have the same weight. The SCI value is the arithmetic mean of the indexes from the areas. The values of the indexes for individual areas were also determined based on the arithmetic mean of the measures. For measures determined on the Likert scale, the following weights were adopted: $(-2 ;-1 ; 0 ; 1 ; 2)$ for the following answers: (strongly disagree, very unsatisfied; somewhat disagree, rather unsatisfied; don't know / no answer, somewhat agree, rather satisfied; strongly agree, very satisfied). This allowed to determine a synthetic answer to the question.

Table 3.

Statistical parameters of the measures

\begin{tabular}{|l|c|c|c|c|c|c|c|c|}
\hline measure & $\mathbf{n}$ & min & max & R & median & average & sd & Vx \\
\hline EC1 & 18 & 3.3 & 20.6 & 17.3 & 9.9 & 10.3 & 4.60 & $45 \%$ \\
\hline EC2 & 20 & -56 & 107 & 163 & 54 & 51.2 & 37.97 & $74 \%$ \\
\hline PE1 & 17 & 33 & 47 & 14 & 40.4 & 39.8 & 3.39 & $9 \%$ \\
\hline PE2 & 20 & 10 & 111 & 101 & 60 & 62.5 & 33.29 & $53 \%$ \\
\hline MA1 & 14 & $4 \%$ & $35 \%$ & $31 \%$ & $27 \%$ & $24 \%$ & $9 \%$ & $38 \%$ \\
\hline MA2 & 20 & -74 & 108 & 182 & 9 & 14.1 & 44.61 & $316 \%$ \\
\hline MO1 & 19 & 0.5 & 35.1 & 34.6 & 15.2 & 15.3 & 8.55 & $56 \%$ \\
\hline MO2 & 20 & -58 & 162 & 220 & 73 & 66.4 & 48.84 & $74 \%$ \\
\hline EN1 & 17 & 1 & 45 & 44 & 13.5 & 14.8 & 13.48 & $91 \%$ \\
\hline EN2 & 20 & -59 & 91 & 150 & 28 & 26.9 & 45.89 & $171 \%$ \\
\hline QL1 & 19 & 7.0 & 28.6 & 21.7 & 11.2 & 12.3 & 4.6 & $37 \%$ \\
\hline QL2 & 20 & 38 & 168 & 130 & 136.5 & 129.6 & 30.92 & $24 \%$ \\
\hline
\end{tabular}

The presented statistical parameters of the measures show that it is impossible to compare them without the standardisation operations, because each one has a different measuring scale. Moreover, the values are expressed in different units (Table 1). In the case, when there was no given value for the measure, the minimum value was imputed. 


\section{Standardisation of measure values}

The comparative analysis of objects with many features is an important element from the point of view of administration, socioeconomic entities or scientific researchers. The results of this research are consumed as sources for assessing the accuracy of decisions made. The methods of this analysis find their place in economics, management, biology and demography.

The idea of multivariate comparative analysis can be reduced to constructing a synthetic indicator, that reflects the criterion for evaluating comparable multivariate objects. The indicator construction procedure, i.e. the method of linear ordering, depends on many factors. The indicator is influenced by the nature of diagnostic features, the scale of measure, the method of weight variation, the method of aggregation, and finally the method of standardisation of features. In most cases, referring to each of these aspects, the researcher is forced to make decisions that may result in changes in the received assessment or ranking. From the point of view of multivariate analysis, the purpose of the work can be defined as the impact of changing the standardisation procedure of variables on the result of linear ordering of multivariate objects.

The choice of standardisation formula depends on the measuring scale, in which we have information about the variable. It is associated with such distribution parameters as: mean, standard deviation, median, median absolute deviation, minimum, maximum, range.

The presented standardisation formulas are implementations of the corresponding linear transformation of a $x_{i}$ variable, which can be written as:

$$
z_{i j}=b_{i} x_{i j}+a_{i}
$$

parameter values $a_{i}, b_{i}$ depend on the standardising formula adopted for the $i$-th variable.

Table 4.

Standardising formulas

\begin{tabular}{|c|l|c|}
\hline \multicolumn{1}{|l|}{ Type } & Formula Name & Formula \\
\hline Z1 & Classical standardisation & $z_{i j}=\frac{\left(x_{i j}-\bar{x}_{j}\right)}{s_{j}}$ \\
\hline Z2 & Weber positional standardisation & $z_{i j}=\frac{\left(x_{i j}-M e_{j}\right)}{1,4826 M A D_{j}}$ \\
\hline Z3 & Unitisation & $z_{i j}=\frac{\left(x_{i j}-\bar{x}_{j}\right)}{r_{j}}$ \\
\hline Z4 & Unitisation with zero minimum & $z_{i j}=\frac{\left(x_{i j}-\min \left\{x_{i j}\right\}\right)}{r_{j}}$ \\
\hline Z5 & Normalisation in range $<-1,1>[-1,1]$ & $z_{i j}=\frac{\left(x_{i j}-\bar{x}_{j}\right)}{\max \left\{\left|x_{i j}-\bar{x}_{j}\right|\right\}}$ \\
\hline Z6 & Quotient transformation 1 & $z_{i j}=\frac{x_{i j}}{s_{j}}$ \\
\hline
\end{tabular}


Cont. table 4.

\begin{tabular}{|c|l|c|}
\hline Z7 & Quotient transformation 2 & $z_{i j}=\frac{x_{i j}}{r_{j}}$ \\
\hline $\mathrm{Z} 8$ & Quotient transformation 3 & $z_{i j}=\frac{x_{i j}}{\max \left\{x_{i j}\right\}}$ \\
\hline $\mathrm{R}^{*}$ & Ranking & \\
\hline
\end{tabular}

* the ranking cannot be described by the formula (1), because it is not a linear transformation. However, this method is mentioned as a means of standardisation.

It is assumed that all variables are stimulants, when the variable is:

- a destimulant, it is transformed into a stimulant according to formula (4),

$$
s_{j}=\max \left\{d_{j}\right\}-d_{j}
$$

- a nominant, it is transformed into a stimulant using formula (5) and then (4).

$$
s_{j}=\left|\tilde{n}-n_{j}\right|
$$

Conversion of a nominant to a stimulant requires knowledge of the reference value $\tilde{n}$ in the event that it is not known, it can be replaced by the median, mean.

All measures that were destimulants, i.e. EC1, EN1, EN2, were replaced according to formula (4) by stimulants. For nominants: PE, MA1, MO1, formula (5) was used, followed by (4). The median value was used as the reference value.

\section{Impact of the standardisation method on the ranking}

The use of standardisation procedures allows for achieving most of the following results, postulates (Kukuła 2000):

- P1: deprivation of titles (units),

- P2: bringing the order of variables to a state of comparability,

- P3: equal to the length of the variation ranges of standardised features,

- P4: possibility of standardising variables that take positive and negative values or only negative values,

- P5: non-negativity of standardised variables,

- P6: the existence of simple formulas that unify the nature of variables.

All methods meet the P1, P2 and P4 postulates. In most cases, it is recommended for the variable to be non-negative and have a stable range of variation. It should be remembered, that a change in the standardising formula makes it necessary to modify the test results and to conduct analyses again.

Depending on the standardisation method chosen, the following distribution parameters were obtained, which are presented in the following tables 5-8, while Table 9 presents city rankings depending on the standardisation method used. 
Table 5.

Variable range in various standardisation methods

\begin{tabular}{|l|r|r|r|r|r|r|r|r|r|}
\hline & \multicolumn{10}{|c|}{ Range } \\
\hline & \multicolumn{1}{|c|}{$\mathbf{Z 1}$} & \multicolumn{1}{|c|}{$\mathbf{Z 2}$} & \multicolumn{1}{c|}{$\mathbf{Z 3}$} & \multicolumn{1}{c|}{$\mathbf{Z 4}$} & \multicolumn{1}{c|}{$\mathbf{Z 5}$} & \multicolumn{1}{c|}{$\mathbf{Z 6}$} & $\mathbf{Z 7}$ & \multicolumn{1}{|c|}{$\mathbf{Z 8}$} & \multicolumn{1}{c|}{$\mathbf{R}$} \\
\hline EC1 & 3.97 & 4.58 & 1.00 & 1.00 & 2.48 & 1.00 & 1.00 & 1.00 & 19.0 \\
\hline EC2 & 4.29 & 5.11 & 1.00 & 1.00 & 2.92 & 1.52 & 1.00 & 1.52 & 19.0 \\
\hline PE1 & 3.42 & 4.24 & 1.00 & 1.00 & 1.79 & 1.89 & 1.00 & 1.89 & 17.5 \\
\hline PE2 & 3.03 & 2.39 & 1.00 & 1.00 & 2.08 & 0.91 & 1.00 & 0.91 & 19.0 \\
\hline MA1 & 3.15 & 4.48 & 1.00 & 1.00 & 1.68 & 1.56 & 1.00 & 1.56 & 18.0 \\
\hline MA2 & 4.08 & 5.20 & 1.00 & 1.00 & 1.94 & 1.69 & 1.00 & 1.69 & 19.0 \\
\hline MO1 & 3.90 & 4.24 & 1.00 & 1.00 & 1.71 & 1.00 & 1.00 & 1.00 & 19.0 \\
\hline MO2 & 4.50 & 5.82 & 1.00 & 1.00 & 2.30 & 1.36 & 1.00 & 1.36 & 19.0 \\
\hline EN_1 & 3.55 & 3.12 & 1.00 & 1.00 & 3.22 & 1.00 & 1.00 & 1.00 & 19.0 \\
\hline EN_2 & 3.27 & 2.28 & 1.00 & 1.00 & 2.34 & 1.65 & 1.00 & 1.65 & 19.0 \\
\hline QL1 & 5.49 & 11.70 & 1.00 & 1.00 & 1.69 & 1.00 & 1.00 & 1.00 & 19.0 \\
\hline QL2 & 4.20 & 4.36 & 1.00 & 1.00 & 3.39 & 0.77 & 1.00 & 0.77 & 18.5 \\
\hline
\end{tabular}

Table 5 shows the transformation of the distribution parameter, which is dispersed. Compared to the original values, it can be seen, that the parameter values are comparable or equal. Only in the case of the Z2 transformation, an outlier can be observed while transforming the QL1 variable.

Table 6.

Average values of the measure for different standardisation methods

\begin{tabular}{|c|c|c|c|c|c|c|c|c|c|}
\hline & \multicolumn{9}{|c|}{ Mean } \\
\hline & Z1 & $\mathrm{Z2}$ & $\mathbf{Z 3}$ & $\mathrm{Z4}$ & $\mathbf{Z 5}$ & Z6 & $\mathbf{Z 7}$ & Z8 & $\mathbf{R}$ \\
\hline EC1 & 0.00 & -0.10 & 0.00 & 0.60 & 0.00 & 0.60 & 0.60 & 0.60 & 10.5 \\
\hline $\mathrm{EC} 2$ & 0.00 & -0.09 & 0.00 & 0.66 & 0.00 & 0.48 & 0.31 & 0.48 & 10.5 \\
\hline PE1 & 0.00 & -0.03 & 0.00 & 0.44 & 0.00 & -0.06 & -0.03 & -0.06 & 10.5 \\
\hline PE2 & 0.00 & 0.06 & 0.00 & 0.52 & 0.00 & 0.56 & 0.62 & 0.56 & 10.5 \\
\hline MA1 & 0.00 & 0.64 & 0.00 & 0.40 & 0.00 & 0.07 & 0.04 & 0.07 & 10.5 \\
\hline MA2 & 0.00 & 0.15 & 0.00 & 0.48 & 0.00 & 0.13 & 0.08 & 0.13 & 10.5 \\
\hline MO1 & 0.00 & 0.01 & 0.00 & 0.41 & 0.00 & 0.41 & 0.41 & 0.41 & 10.5 \\
\hline MO2 & 0.00 & -0.18 & 0.00 & 0.57 & 0.00 & 0.41 & 0.30 & 0.41 & 10.5 \\
\hline EN_1 & 0.00 & -0.08 & 0.00 & 0.69 & 0.00 & 0.69 & 0.69 & 0.69 & 10.5 \\
\hline EN 2 & 0.00 & -0.02 & 0.00 & 0.57 & 0.00 & 0.30 & 0.18 & 0.30 & 10.5 \\
\hline QL1 & 0.00 & 0.23 & 0.00 & 0.41 & 0.00 & 0.41 & 0.41 & 0.41 & 10.5 \\
\hline QL2 & 0.00 & -0.23 & 0.00 & 0.70 & 0.00 & 0.77 & 1.00 & 0.77 & 10.5 \\
\hline
\end{tabular}

Tables 7 and 8 present two classic parameters, mean and standard deviation. In this case, homogeneity of results is maintained, and in the case of Z1 standardisation, equality.

Table 7.

Standard deviation values of the measure for various standardisation methods

\begin{tabular}{|c|c|c|c|c|c|c|c|c|c|}
\hline & \multicolumn{9}{|c|}{ standard deviation } \\
\hline & $\mathbf{Z 1}$ & $\mathbf{Z 2}$ & $\mathbf{Z 3}$ & $\mathrm{Z4}$ & $\mathbf{Z 5}$ & Z6 & $\mathbf{Z 7}$ & $\mathbf{Z 8}$ & $\mathbf{R}$ \\
\hline EC1 & 1.00 & 1.15 & 0.25 & 0.25 & 0.62 & 0.25 & 0.25 & 0.25 & 5.91 \\
\hline $\mathrm{EC} 2$ & 1.00 & 1.19 & 0.23 & 0.23 & 0.68 & 0.35 & 0.23 & 0.35 & $\overline{5.91}$ \\
\hline PE1 & 1.00 & 1.24 & 0.29 & 0.29 & 0.52 & 0.55 & 0.29 & 0.55 & 5.88 \\
\hline PE2 & 1.00 & 0.79 & 0.33 & 0.33 & 0.69 & 0.30 & 0.33 & 0.30 & 5.91 \\
\hline
\end{tabular}


Cont. table 7.

\begin{tabular}{|l|r|r|r|r|r|r|r|r|r|}
\hline MA1 & 1.00 & 1.42 & 0.32 & 0.32 & 0.53 & 0.50 & 0.32 & 0.50 & 5.88 \\
\hline MA2 & 1.00 & 1.27 & 0.25 & 0.25 & 0.48 & 0.41 & 0.25 & 0.41 & 5.92 \\
\hline MO1 & 1.00 & 1.09 & 0.26 & 0.26 & 0.44 & 0.26 & 0.26 & 0.26 & 5.91 \\
\hline MO2 & 1.00 & 1.29 & 0.22 & 0.22 & 0.51 & 0.30 & 0.22 & 0.30 & 5.92 \\
\hline EN_1 & 1.00 & 0.88 & 0.28 & 0.28 & 0.91 & 0.28 & 0.28 & 0.28 & 5.87 \\
\hline EN_2 & 1.00 & 0.70 & 0.31 & 0.31 & 0.72 & 0.50 & 0.31 & 0.50 & 5.91 \\
\hline QL1 & 1.00 & 2.13 & 0.18 & 0.18 & 0.31 & 0.18 & 0.18 & 0.18 & 5.92 \\
\hline QL2 & 1.00 & 1.04 & 0.24 & 0.24 & 0.81 & 0.18 & 0.24 & 0.18 & 5.91 \\
\hline
\end{tabular}

Table 8.

Measure median values for various standardisation methods

\begin{tabular}{|c|c|c|c|c|c|c|c|c|c|}
\hline & \multicolumn{9}{|c|}{ Median } \\
\hline & $\mathrm{Z1}$ & $\mathrm{Z2}$ & $\mathbf{Z 3}$ & $\mathrm{Z4}$ & $\mathrm{Z5}$ & Z6 & $\mathbf{Z 7}$ & $\mathbf{Z 8}$ & $\mathbf{R}$ \\
\hline EC1 & 0.09 & 0.00 & 0.02 & 0.62 & 0.06 & 0.62 & 0.62 & 0.62 & 10.5 \\
\hline EC2 & 0.08 & 0.00 & 0.02 & 0.67 & 0.05 & 0.50 & 0.33 & 0.50 & 10.5 \\
\hline PE1 & 0.02 & 0.00 & 0.01 & 0.45 & 0.01 & -0.05 & -0.03 & -0.05 & 10.0 \\
\hline PE2 & -0.08 & 0.00 & -0.02 & 0.50 & -0.05 & 0.54 & 0.59 & 0.54 & 10.5 \\
\hline MA1 & -0.45 & 0.00 & -0.14 & 0.26 & -0.24 & -0.15 & -0.10 & -0.15 & 9.5 \\
\hline MA2 & -0.11 & 0.00 & -0.03 & 0.46 & -0.05 & 0.08 & 0.05 & 0.08 & 10.5 \\
\hline MO1 & -0.01 & 0.00 & 0.00 & 0.41 & -0.01 & 0.41 & 0.41 & 0.41 & 10.5 \\
\hline MO2 & 0.14 & 0.00 & 0.03 & 0.60 & 0.07 & 0.45 & 0.33 & 0.45 & 10.5 \\
\hline EN_1 & 0.09 & 0.00 & 0.03 & 0.72 & 0.08 & 0.72 & 0.72 & 0.72 & 10.0 \\
\hline EN_2 & 0.02 & 0.00 & 0.01 & 0.58 & 0.02 & 0.31 & 0.19 & 0.31 & 10.5 \\
\hline QL1 & -0.11 & 0.00 & -0.02 & 0.39 & -0.03 & 0.39 & 0.39 & 0.39 & 10.5 \\
\hline QL2 & 0.22 & 0.00 & 0.05 & 0.76 & 0.18 & 0.81 & 1.05 & 0.81 & 10.5 \\
\hline
\end{tabular}

The last of the measures presented is the positional measure of the central tendency, which is the median (Table 8). Also, in this case, the parameter distribution was homogeneous or identical.

The fulfilment of the remaining postulates is as follows:

- P3 - not all lead to equal lengths of variation intervals, in most cases they are comparable

- P5 - not all provide non-negativity of standardised features; however, this is due to the standardisation formula

- P6 - in general, rank does not meet this postulate; however, the algorithm is simple and implemented in all data analysis packages.

At this stage, none of the standardisation methods presented were rejected. It was recognised that they all satisfactorily meet all postulates.

The SCI value was determined for them on the basis of standardised variables. Then, based on the value of the index, a ranking of individual cities was created (Table 9). As can be seen, the positions in the ranking for individual standardisation methods are similar. The first four positions are Vienna, Dublin, Helsinki and Amsterdam. Medium European countries. Interestingly, the next positions are held by the capitals of small countries: Tallinn, Riga, Luxembourg, Vilnius, Valletta, Ljubljana. Berlin, Brussels, Paris and Nicosia are next. Nicosia apparently does not fit into this group, but apart from its separateness, the residents and 
problems are analogous to the other three capitals. Other capitals seem to form the last group of capitals similar in terms of size and problems. Warsaw is also in the last group. It seems that the position of the capital corresponds with the position of the state in a certain structure. The statement that the capital is the showcase of the country is fully justified. The last group is a group of capitals of European countries, in which there is a crisis, an economic slowdown, and residents are demonstrating their dissatisfaction on the streets.

Table 9.

Ranking results for various standardisation methods

\begin{tabular}{|l|l|l|l|l|l|l|l|l|l|}
\hline & $\mathbf{Z 1}$ & $\mathbf{Z 2}$ & $\mathbf{Z 3}$ & $\mathbf{Z 4}$ & $\mathbf{Z 5}$ & $\mathbf{Z 6}$ & $\mathbf{Z 7}$ & $\mathbf{Z 8}$ & $\mathbf{R}$ \\
\hline Vienna & 1 & 1 & 1 & 1 & 1 & 1 & 1 & 1 & 3 \\
\hline Dublin & 2 & 2 & 2 & 2 & 2 & 2 & 2 & 2 & 1 \\
\hline Helsinki & 4 & 4 & 3 & 3 & 4 & 3 & 3 & 3 & 5 \\
\hline Amsterdam & 3 & 3 & 4 & 4 & 3 & 4 & 4 & 4 & 4 \\
\hline Tallinn & 5 & 5 & 5 & 5 & 5 & 5 & 5 & 5 & 2 \\
\hline Riga & 6 & 6 & 6 & 6 & 7 & 6 & 6 & 6 & 8 \\
\hline Luxembourg & 7 & 13 & 7 & 7 & 6 & 7 & 7 & 7 & 6 \\
\hline Vilnius & 8 & 7 & 8 & 8 & 8 & 8 & 8 & 8 & 7 \\
\hline Valletta & 9 & 8 & 9 & 9 & 9 & 9 & 9 & 9 & 9 \\
\hline Ljubljana & 10 & 12 & 10 & 10 & 10 & 10 & 10 & 10 & 11 \\
\hline Berlin & 11 & 10 & 12 & 12 & 11 & 14 & 12 & 14 & 10 \\
\hline Brussels & 12 & 9 & 13 & 13 & 13 & 11 & 13 & 11 & 14 \\
\hline Nicosia & 13 & 14 & 11 & 11 & 12 & 12 & 11 & 12 & 13 \\
\hline Paris & 14 & 11 & 14 & 14 & 14 & 13 & 14 & 13 & 12 \\
\hline Bratislava & 15 & 15 & 15 & 15 & 15 & 15 & 15 & 15 & 15 \\
\hline Warsaw & 16 & 16 & 17 & 17 & 18 & 16 & 17 & 16 & 16 \\
\hline Lisbon & 17 & 17 & 16 & 16 & 16 & 17 & 16 & 17 & 17 \\
\hline Madrid & 18 & 18 & 18 & 18 & 17 & 18 & 18 & 18 & 18 \\
\hline Athens & 19 & 19 & 20 & 20 & 20 & 19 & 20 & 19 & 19 \\
\hline Rome & 20 & 20 & 19 & 19 & 19 & 20 & 19 & 20 & 20 \\
\hline
\end{tabular}

As can be seen, the results obtained using different standardisation methods are very similar. The determined Pearson's linear correlation coefficient between the variables indicates a linear relationship between the results. The smallest factor value is 0.93 . Comparing the methods directly, the Z1 method is the closest to the others - the highest average value of the Pearson's correlation coefficient.

Table 10.

Pearson's linear correlation coefficients between results

\begin{tabular}{|c|c|c|c|c|c|c|c|c|c|}
\hline & $\mathrm{Z1}$ & $\mathbf{Z 2}$ & $\mathbf{Z 3}$ & $\mathbf{Z 4}$ & $\mathbf{Z 5}$ & $\mathrm{Z6}$ & Z7 & $\mathbf{Z 8}$ & $\mathbf{R}$ \\
\hline $\mathrm{Z1}$ & 1 & & & & & & & & \\
\hline $\mathrm{Z2}$ & 0.95 & 1 & & & & & & & \\
\hline $\mathrm{Z3}$ & 0.99 & 0.94 & 1 & & & & & & \\
\hline $\mathrm{Z4}$ & 0.99 & 0.94 & 1 & 1 & & & & & \\
\hline$\overline{Z 5}$ & 0.99 & 0.93 & 0.99 & 0.99 & 1 & & & & \\
\hline Z6 & 0.99 & 0.95 & 0.99 & 0.99 & 0.98 & 1 & & & \\
\hline Z7 & 0.99 & 0.94 & 1 & 1 & 0.99 & 0.99 & 1 & & \\
\hline $\mathrm{Z8}$ & 0.99 & 0.95 & 0.99 & 0.99 & 0.98 & 1 & 0.99 & 1 & \\
\hline $\mathrm{R}$ & 0.98 & 0.93 & 0.97 & 0.97 & 0.97 & 0.96 & 0.97 & 0.96 & 1 \\
\hline
\end{tabular}


From the point of view of the entire ranking, the impact of the standardisation method on the whole ranking is not very important.

If the analysis is to concern individual assessed objects, then the choice of method matters. Table 11 shows how the maximum distance between positions in the ranking is transformed and the number of positions on which other objects are located. For methods that were not fully consistent, the minimum number of inconsistent positions is 6 , with an average inconsistency of 9.74. Which means that, with 20 objects, almost half of them hold other places in the ranking. In terms of these two assessments, the $\mathrm{Z} 1$ method is characterised by the average smallest number of inconsistent positions, as well as the smallest maximum distance between positions.

Table 11.

Differences in rankings for different standardisation methods

\begin{tabular}{|c|c|c|c|c|c|c|c|c|c|c|}
\hline & \multicolumn{9}{|c|}{ The maximum distance between positions in the ranking } \\
\hline & & $\mathbf{Z 1}$ & $\mathbf{Z 2}$ & $\mathbf{Z 3}$ & $\mathbf{Z 4}$ & $\mathbf{Z 5}$ & Z6 & $\mathbf{Z 7}$ & $\mathbf{Z 8}$ & $\mathbf{R}$ \\
\hline \multirow{9}{*}{ 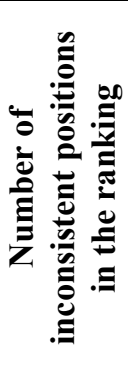 } & $\mathrm{Z1}$ & & 6 & 2 & 2 & 2 & 3 & 2 & 3 & 3 \\
\hline & $\mathrm{Z2}$ & 8 & & 6 & 6 & 7 & 6 & 6 & 6 & 7 \\
\hline & Z3 & 9 & 14 & & 0 & 1 & 2 & 0 & 2 & 3 \\
\hline & $\mathrm{Z4}$ & 9 & 14 & 0 & & 1 & 2 & 0 & 2 & 3 \\
\hline & Z5 & 9 & 14 & 8 & 8 & & 3 & 1 & 3 & 3 \\
\hline & $\mathrm{Z6}$ & 6 & 10 & 8 & 8 & 12 & & 2 & 0 & 4 \\
\hline & $\mathrm{Z7}$ & 9 & 14 & 0 & 0 & 8 & 8 & & 2 & 3 \\
\hline & Z8 & 6 & 10 & 8 & 8 & 12 & 0 & 8 & & 4 \\
\hline & $\mathrm{R}$ & 12 & 12 & 16 & 16 & 17 & 12 & 16 & 12 & \\
\hline
\end{tabular}

\section{Conclusions}

Analysing the results of the ranking, it can be stated, that the results match the small number of variables with other presented rankings, based on a much larger number of variables. From this point of view, it can be acknowledged that the results obtained are reliable.

The issue of choosing a standardisation method is relevant for the construction of rankings. If we are interested in the entire ranking and look at the ranking in a global way, this relevance clearly decreases, the arrays are very similar. The objects change their position in the ranking by one or two positions, and the maximum change in the example did not exceed seven positions. In the case, when we want to select an object based on the ranking, the selection of standardisation method affects the position of individual objects. Therefore, it should be specified exactly how standardisation should be adopted.

Based on the results obtained, it can be concluded that $\mathrm{Z} 1$ standardisation is a recommended method. For this method we obtain the smallest number of inconsistent positions in ranking and the minimal maximum of distance between positions in ranking. If other standardisation methods are used, one should consider the substantive justification for their application in a particular case. 
Warsaw ranks 16th or 17th in the presented rankings, depending on the standardization method. In these positions occurs interchangeably with Lisbon.

\section{Acknowledgements}

This paper was financed from the resources of the Silesian University of Technology, project no. BK-235/ROZ-1/2020 (13/010/BK_20/0042).

\section{References}

1. Ahvenniemi, H., Huovila, A., Pinto-Seppä, I., \& Airaksinen, M. (2017). What are the differences between sustainable and smart cities? Cities, 60, pp. 234-245.

2. Albino, V., Berardi, U., \& Dangelico, R.M. (2015). Smart cities: Definitions, dimensions, performance, and initiatives. Journal of urban technology, 22(1), pp. 3-21.

3. Berrone P., Ricart J.E., Duch A., Carrasco C. (2019). IESE Cities in Motion Index 2019, IESE, ST-509-E, 05/2019. DOI: https://dx.doi.org/10.15581/018.ST-509.

4. Bosch, P., Jongeneel, S., Neumann H.-M., Branislav I., Huovila, A., Airaksinen M., Pinto-Seppä I. (2017a). Recommendations for a Smart City index. CITYkeys - Smart city performance measurement framework. DOI: 10.13140/RG.2.2.20190.74562, 15.03.2019.

5. Bosch, P., Jongeneel, S., Rovers, V., Neumann, H.-M., Airaksinen, M., \& Huovila, A. (2017b). CITYkeys indicators for smart city projects and smart cities. CITYkeys - Smart city performance measurement framework. DOI: 10.13140/RG.2.2.17148.23686, 15.03.2019.

6. Bosch, P., Jongeneel, S., Rovers, V., Neumann, H.-M., Airaksinen, M., \& Huovila, A. (2017c). CITYkeys indicators for smart city projects and smart cities. DOI: 10.13140/ RG.2.2.17148.23686, 15.03.2019.

7. Giffinger, R., Fertner, C., Kramar, H., Kramar, H., Kalasek, R., Pichler-Milanovic, N., Meijers, E. (2007). Smart Cities. Ranking of European medium-sized cities. Centre for Regional Science, Vienna University of Technology, http://www.smart-cities.eu/ download/smart_cities_final_report.pdf, 15.03.2019.

8. Huovila, A., Penttinen, T., Airaksinen, M., Pinto-Seppä, I., Piira, K., \& Penttinen, T. (2016, September). Smart city performance measurement system. Proceedings of the 41th IAHS World Congress Sustainability Innovation for the Future, Algarve, Portugal, pp. 13-16. 
9. Kukuła, K. (1989). Statystyczna analiza strukturalna i jej zastosowanie w sferze usług produkcyjnych dla rolnictwa. Zeszyty Naukowe AE $w$ Krakowie, Seria specjalna: Monografie, 89, p. 256.

10. Kukuła, K. (2000) Metoda unitaryzacji zerowanej. Warszawa: PWN.

11. Lombardi, P., Giordano, S., Caragliu, A., Del Bo, C., Deakin, M., Nijkamp, P., \& Kourtit, K. (2011). An advanced triple-helix network model for smart cities performance. Vrije Universiteit Amsterdam, Research Memorandum, 2011-45, http://degree.ubvu.vu.nl/ repec/vua/wpaper/pdf/20110045.pdf, 15.03.2019.

12. Smart City PROFILES (2013). Ergebnisse. 7.6.2013. http://www.smartcities.at/assets/03Begleitmassnahmen/SmartCity-PDF-INTRO.pdf, 15.03.2019.

13. Sojda A., Owczarek T., Wolny M. (2018). Smart City w ujęciu zorientowanym na dane Polska w bazie Eurostat. Zeszyty Naukowe Politechniki Ślaskiej, seria Organizacja i Zarządzanie, 130. http://dx.doi.org/10.29119/1641-3466.2018.130.46.

14. Stankovic, J., Dzunic, M., Džunić, Ž., \& Marinkovic, S. (2015). A multi-criteria evaluation of the European cities' smart performance: Economic, social and environmental aspects. Zbornik radova Ekonomskog fakulteta u Rijeci, časopis za ekonomsku teoriju i praksuProceedings of Rijeka Faculty of Economics. Journal of Economics and Business, 35(2), pp. 519-550.

15. Svítek, M., Skobelev, P., \& Kozhevnikov, S. (2020). Smart City 5.0 as an Urban Ecosystem of Smart Services. 10.1007/978-3-030-27477-1_33.

16. Szczech-Pietkiewicz, E. (2015). Smart city-próba definicji i pomiaru. Prace Naukowe Uniwersytetu Ekonomicznego we Wrocławiu. Gospodarka lokalna w teorii i praktyce, 391.

17. Tahir, Z., \& Malek, J.A. (2016). Main criteria in the development of smart cities determined using analytical method. Planning Malaysia Journal, 14(5).

18. UCLG (2012). Smart Cities Study: International study on the situation of ICT, innovation and knowledge in cities. Bilbao. http://www.uclg-digitalcities.org/app/uploads/ 2015/06/en_smartcitiesstudy.pdf, 15.03.2019. 